\title{
Distribution of aquatic insects in phumdis (floating island) of Loktak Lake, Manipur, northeastern India
}

\author{
Kiranbala Takhelmayum ${ }^{1} \&$ Susmita Gupta ${ }^{2}$ \\ 1,2 Department of Ecology \& Environmental Science, Assam University, Silchar, Assam 788011, India \\ Email: ${ }^{1}$ kirantakhelmayum@yahoo.com, ${ }^{2}$ susmita_au@rediffmail.com (corresponding author)
}

\begin{abstract}
A study was made on the temporal fluctuations of distribution of aquatic insects around Phumdi Live (PL), Phumd Mixed (PM) and Phumdi Dry (PD) areas of Loktak Lake. Phumdis are a heterogeneous mass of soil, vegetation and organic matter. The study revealed the presence of predators, and the absence of herbivores and detritivores in both PL and PM, the PD area was totally devoid of insects. Although both the habitats supported the same predator groups hemiptera and odonata, diversity and density in terms of family and species were higher in PL than in PM. Temporal fluctuations revealed that the ShannonWeiner's Diversity Index values were highest in June for both PL (0.726) and PM (0.47). In both the sites the highest density was recorded in February. The relative abundance of hemiptera was higher than that of odonata in most of the months in PL. Phumdi Mixed was represented by one species of hemiptera only, in the month of February and dominated by odonates otherwise. Community composition of odonata larvae did not show any difference between the two habitats. Although the study revealed low diversity and density of insects in both sites, the PL community provided a better habitat to aquatic insects than that of PM. These are of value as fish food and in turn for fish production.
\end{abstract}

Keywords: Phumdis, hemiptera, odonata, Loktak Lake, insect, diversity, density.

Date of publication (online): 26 June 2011

Date of publication (print): 26 June 2011

ISSN $0974-7907$ (online) | 0974-7893 (print)

Editor: R. Ramanibai

Manuscript details:

Ms \# 02526

Received 26 July 2010

Final revised received 04 January 2011

Finally accepted 18 May 2011

Citation: Takhelmayum, K. \& S. Gupta (2011). Distribution of aquatic insects in phumdis (floating island) of Loktak Lake, Manipur, northeastern India. Journal of Threatened Taxa 3(6): 1856-1861.

Copyright: (C) Kiranbala Takhelmayum \& Susmita Gupta 2011. Creative Commons Attribution 3.0 Unported License. JoTT allows unrestricted use of this article in any medium for non-profit purposes, reproduction and distribution by providing adequate credit to the authors and the source of publication.

Acknowledgements: The authors wish to thank Prof. Rajmuhon Singh Department of Chemistry, Manipur University, Manipur, India, for his help and cooperation during the field and laboratory studies. Sincere thanks go to Dr. Animesh Bal, Zoological Survey of India, Kolkata for his help in hemipteran insect identification.

OPEN ACCESS | FREE DOWNLOAD

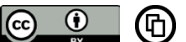

Loktak Lake, a Ramsar site, $\left(93^{\circ} 46^{\prime}-93^{0} 55^{\prime} \mathrm{E} \&\right.$ $\left.24^{0} 25^{\prime}-24^{0} 42^{\prime} \mathrm{N}\right)$ is the largest fresh water lake $(26 \mathrm{~km}$ long and $13 \mathrm{~km}$ wide with $980 \mathrm{~km}^{2}$ catchment area) in the Manipur State of northeastern India (Fig. 1). The unique feature of the lake is the floating island called phumdis which form the Kaibul Lamjao National Park (the only home of Rucervus eldii eldii). Phumdis, are a heterogeneous mass of soil, vegetation and organic matter at various stages of decomposition (Image 1). They float on lake water with about one-fifth of thickness above and four-fifths under the water surface appearing in three distinct vertical zones, lying one above the other. The uppermost root zone is generally $0-15 \mathrm{~cm}$ thick followed by the next mat zone of 25$65 \mathrm{~cm}$ and the lowermost peat zone $0-25 \mathrm{~cm}$. Freefloating plants, such as water hyacinth and partly decomposed roots and rhizomes contribute greatly to its development. There are three types of phumdis. They are Phumdi Live (PL) mostly consisting of paragrass like Brachairia mutica, Alternathara phitoxiroides and plants like Salvinia calcullata, Cyperus difformis and Heydichium spicatum etc; Phumdi Mixed (PM) comprising both live and dry paragrass and plants, and Phumdi Dry (PD) comprising dead, dry paragrass and plants (Singh et al. 2003). Phumdis provide a biological sink to the key nutrients and govern the water quality and nutrient dynamics of the lake by absorbing most of the nutrients and accumulating them in their tissues (WISA \& LDA 2002).

Faunal distribution and their assemblage is strongly dependent on the composition and structure of vegetation (Korkeamaki \& Suhonen 2002) and invertebrates are recognized as an essential food source for nesting and juvenile water fowl, fish, and amphibians in wetland systems (Swanson et al. 1979; Batzer et al. 1999). There are several studies on invertebrates, mainly aquatic insects in different fresh water systems or aquatic insects associated with individual plant species or with the plant community 


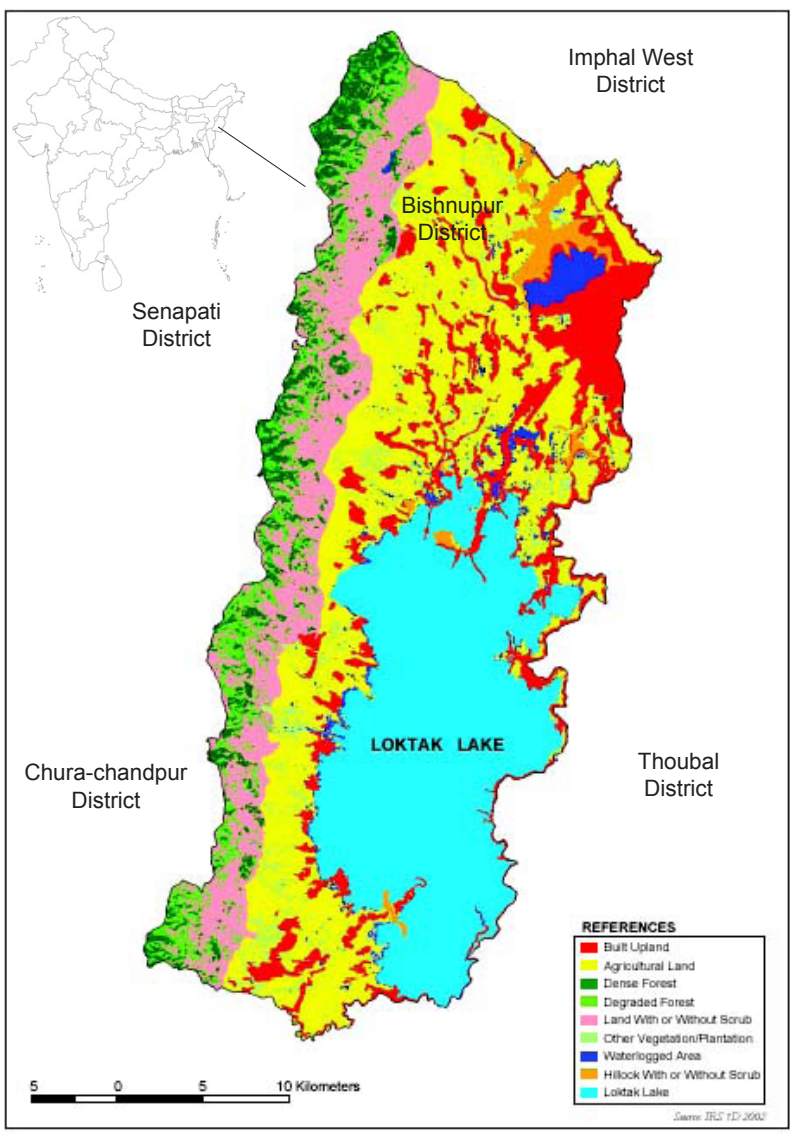

Figure 1. Loktak map, Manipur (source - Envis Centre in Biogeochemistry, J.N.U, New Delhi)

(Wellborn \& Robinson 1987; Parsons \& Malthews 1995; Das \& Gupta 2010; Hazarika \& Goswami 2010). No study on the insects of Loktak Lake is on record. In this study we attempt to find the temporal fluctuations of distribution of aquatic insects around different types of phumdis of Loktak Lake in terms of diversity and density. Extrapolation of this data might be of help to the planners in chalking out fish culture and lake management programmes.

\section{Materials and Methods}

Aquatic insects were collected from the southwestern region of the lake through an extensive survey around the PL, PM and PD habitats during February to July, 2008 whereby the vegetation was disturbed and a circular net (mesh size $60 \mu \mathrm{m})$ was dragged around the vegetation for one minute (Subramanian \& Sivaramakrishnan 2007). Three such drags constituted a sample. Collected insects were immediately sorted and preserved in $70 \%$ ethyl alcohol. They were later identified using a Dewinter advance stereozoom

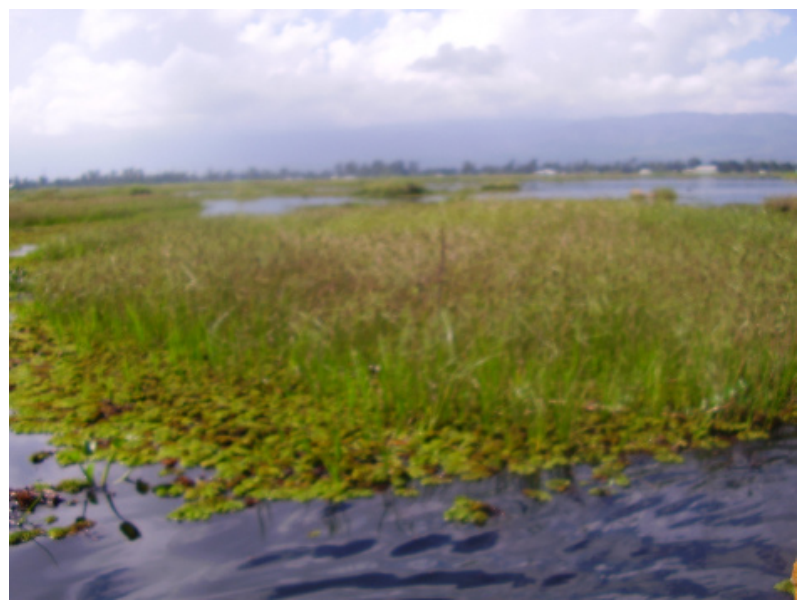

Image 1. Phumdis (floating mat) of Loktak Lake

Microscope with the help of standard keys (Kumar 1973a,b; Bal \& Basu 1994a,b; Westfall \& Tennessen 1996; ZSI 2004). A number of identified insects were confirmed in the entomological laboratory of the Zoological Survey of India. Diversity indices were worked out using the package Biodiversity Professional Version 2.

\section{Results and Discussion}

PL and PM areas were represented by two orders of insects, Hemiptera and Odonata; the PD area was devoid of insects. Seven species belonging to four families were recorded around PL. They were Ranatra varipes and Laccotrephes ruber (Nepidae), Gerris sp. (Gerridae), Diplonychus rusticus (Belostomatidae) belonging to the suborder Heteroptera, order Hemiptera and Tramea sp., Leucorrhinia sp., Sympetrum sp. belonging to the family Libellulidae of the suborder Anisoptera, order Odonata (Images $2 \mathrm{a}-\mathrm{g}$ ). Around PM only four species belonging to two families, and two subfamilies were recorded. They were Diplonychus rusticus belonging to the family Belostomatidae and all three Odonata species recorded in PL. Among the families, Libellulidae was the most prominent, being present throughout in both sites (Table 1).

The Shannon-Weiner's Diversity Index values around PL were relatively higher in most of the months than that of PM. In both sites, Shannon H' were highest in June, 0.726 for PL and 0.47 for PM. Around PL, the highest evenness was recorded in March and the lowest in July, while the Berger Parker Dominance index was just the reverse. In contrast, around PM the highest evenness was recorded in June and the lowest in April 
Table 1. Distribution of aquatic insects around Phumdi Live (PL) and Phumdi Mixed (PM) area of Loktak Lake.

\begin{tabular}{|c|c|c|c|c|}
\hline Order & $\begin{array}{l}\text { Family I } \\
\text { subfamily }\end{array}$ & Species & PL & PM \\
\hline \multirow{4}{*}{ Hemiptera } & $\begin{array}{l}\text { Nepidae } \\
\text { Ranantrinae }\end{array}$ & Ranatra varipes & + & - \\
\hline & Nepinae & Laccotrephes ruber & + & - \\
\hline & $\begin{array}{l}\text { Gerridae } \\
\text { Gerrinae }\end{array}$ & Gerris sp. & + & - \\
\hline & $\begin{array}{l}\text { Belostomatidae } \\
\text { Belostomatinae }\end{array}$ & $\begin{array}{l}\text { Diplonychus } \\
\text { rusticus }\end{array}$ & + & + \\
\hline \multirow{3}{*}{ Odonata } & $\begin{array}{l}\text { Libellulidae } \\
\text { Trameinae }\end{array}$ & Tramea sp. & + & + \\
\hline & Leucorrhininae & Leucorrhinia sp. & + & + \\
\hline & Sympetrinae & Sympetrum sp. & + & + \\
\hline
\end{tabular}

Table 2. Temporal variation of Shannon Weiner diversity index ( $\left.\mathrm{H}^{\prime}\right)$, Evenness index $(\mathrm{J})$ and Berger Parker index of dominance (d) around Phumdi Live (PL) and Phumdi Mixed (PM) habitat of Loktak Lake

\begin{tabular}{|c|c|c|c|c|c|c|c|}
\hline Habitat & $\begin{array}{c}\text { Diversity } \\
\text { index }\end{array}$ & Feb & Mar & Apr & May & Jun & Jul \\
\hline \multirow{7}{*}{ PL } & $\mathrm{H}^{\prime}$ & 0.714 & 0.598 & 0.657 & 0.292 & 0.726 & 0.353 \\
\cline { 2 - 8 } & $\mathrm{J}^{\prime}$ & 0.918 & 0.993 & 0.94 & 0.971 & 0.933 & 0.739 \\
\cline { 2 - 8 } & $\mathrm{d}$ & 0.313 & 0.286 & 0.319 & 0.6 & 0.308 & 0.688 \\
\cline { 2 - 8 } & $1 / \mathrm{d}$ & 3.2 & 3.5 & 3.133 & 1.667 & 3.25 & 1.455 \\
\hline \multirow{7}{*}{$\mathrm{PM}$} & $\mathrm{H}^{\prime}$ & 0.423 & 0.292 & 0.398 & 0.426 & 0.47 & 0 \\
\cline { 2 - 8 } & $\mathrm{J}^{\prime}$ & 0.886 & 0.971 & 0.834 & 0.893 & 0.985 & 0 \\
\cline { 2 - 8 } & $\mathrm{d}$ & 0.48 & 0.6 & 0.545 & 0.556 & 0.375 & 0 \\
\cline { 2 - 8 } & $1 / \mathrm{d}$ & 2.083 & 1.667 & 1.833 & 1.8 & 2.667 & 0 \\
\hline
\end{tabular}

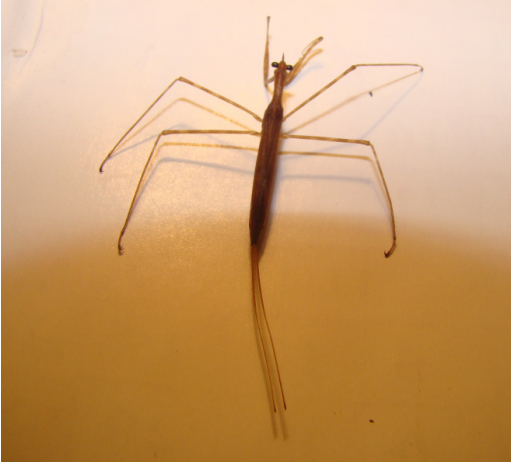

Image 2a. Ranatra varipes

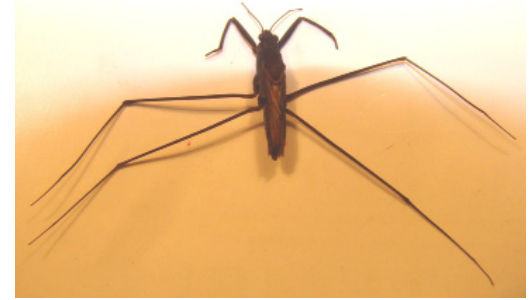

Image 2b. Gerris sp.
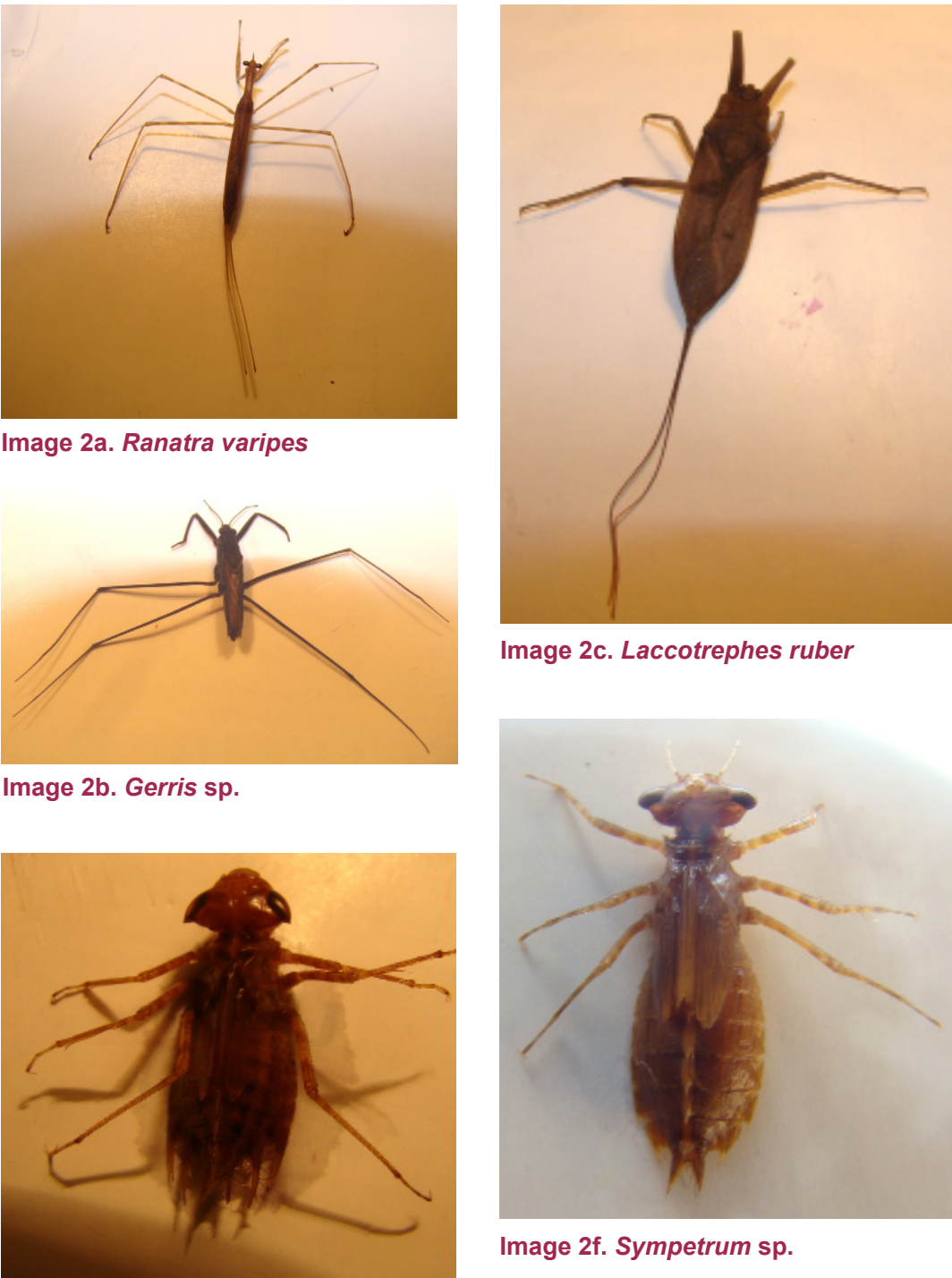

Image 2c. Laccotrephes ruber

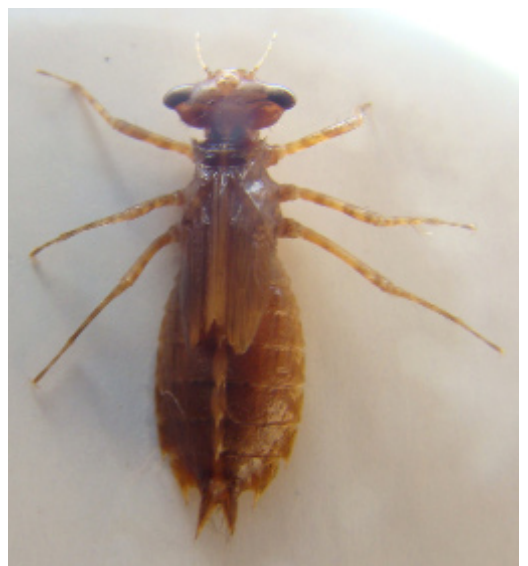

Image 2g. Diplonychus rusticus

Image 2f. Sympetrum sp.
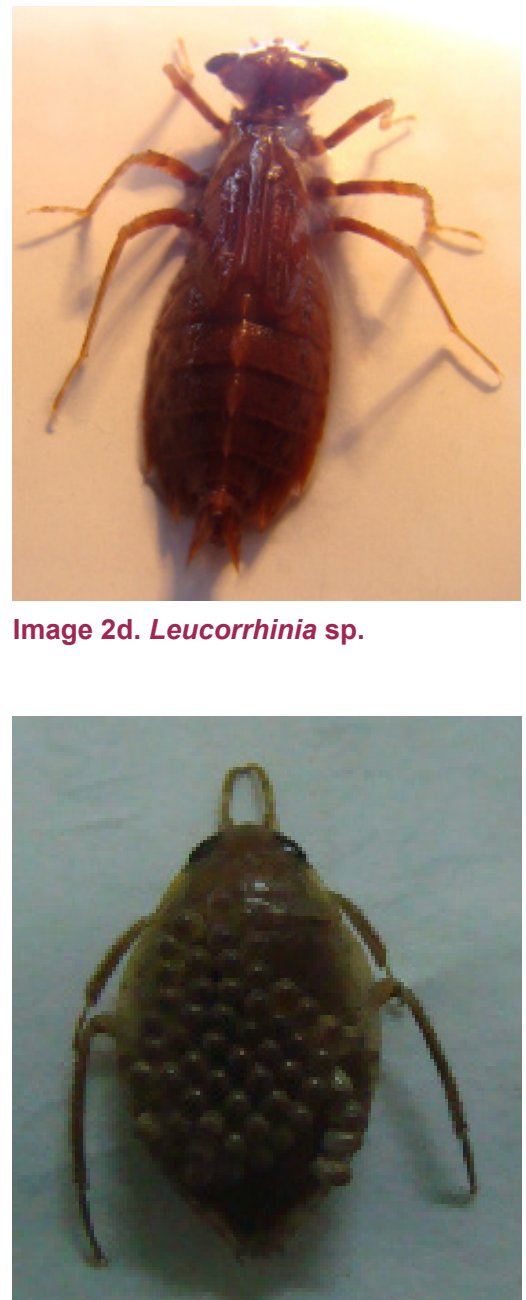

Image 2d. Leucorrhinia sp.

Image 2e. Tramea sp. 


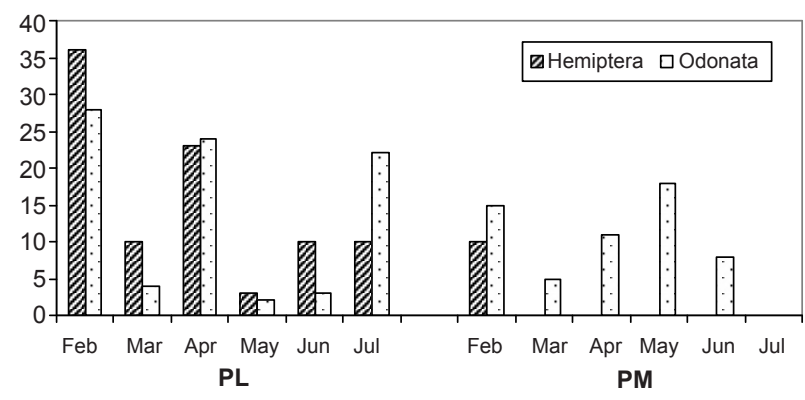

Figure 2. Temporal fluctuation of density (no./unit time) of two orders of insects around Phumdi Live (PL) and Phumdi Mixed (PM) area.

(Table 2). The density of insects for both the orders was recorded the highest in February and the lowest in May in the PL area. Around PM, while Odonata was recorded throughout with the highest density in May, hemipterans were present only in the month of February (Fig. 2).

The Loktak Lake has been declared as a Ramsar site because of its floating mass of vegetation phumdis, large water fowl population and unique fish breeding ground below the phumdis. It was also included in the Montreux Record, in 1993, due to several ecological problems (Ramsar Convention Bureau 1997). This study recorded low diversity and density of insects in both sites compared to other fresh water lakes like Kanjli Lake (Kaur et al. 2004) and Harike Wetland (Bath \& Kaur 1997) in Punjab. The study revealed the presence of only predators in both sites while herbivores-detritivores were totally absent. The absence of sensitive groups like Ephemeroptera in both sites might be an indication of perturbations of the system (Rosenberg \& Resh 1993). Another important factor could be predation pressure as aquatic insects are the food of insectivorous fishes, and are an important component in the diets of both nesting and juvenile waterfowl. Lake Loktak supports a significant population of water fowl and harbours a variety of air breathing insectivorous fish (Singh 1992; Singh 1999).

The study recorded qualitative and quantitative differences in insect communities between the two sites, PL and PM, during the investigation period. It also recorded an absence of insects around PD. As availability of invertebrates depends on the availability of high quality plant habitat (Swanson et al. 1979) and plants are utilized by aquatic insects directly as a food source, sites for oviposition, and sources of respiratory oxygen (Rooke 1984) it could be said that the PD area comprising of dead and dry plants could not meet their requirements for survival. Higher diversity and density of aquatic insects in PL than in PM could be attributed to the luxuriant vegetation of the PL area which might have attracted more insects that looked for refuge, oviposition site and food, as their assemblage is strongly dependent on the composition, structure and greater surface area provided by the vegetation types (Merritt \& Cummins 1996; Korkeamaki \& Suhonen 2002). Further local distribution patterns of macro-invertebrate communities could be significantly influenced by the competitors and predators of the particular habitat (Hart \& Resh 1980). The PM area being composed of dry and live plants was not a good foraging ground for the predators. The presence of only Diplonycus rusticus in PM in the month of February in a much higher number than that in PL, mostly male with eggs on their back, could be due to the fact that the males looked for a safe area where predator pressure might be comparatively less for protecting their heavy egg mass laid by their female partners which made them less mobile reducing their foraging ability and increasing susceptibility to predators (Mc Gavin 1993; Kight et al.1995). Chilton (1990) also suggested that the close proximity of differing plant communities could allow for emigration and immigration of invertebrates between macrophytes.

High association of Odonates with vegetation in aquatic systems has been recorded by several workers (Muli et al. 2000; Salmah et al. 2006). The absence of differences in the community composition of Odonata larvae during the investigation period between the two habitats agreed with the study on the three genera of Namibian Libellulidae (Frank et al. 2005). However, Odonata population was low in the PM area in most of the months and showed temporal fluctuation in both the sites. In May while their population decreased in PL, representing only Sympetrum sp., in PM it increased with the presence of all the three species. This variability of population could be attributed to several factors like mortality, hatching of eggs, emergence, predation and availability of food. Preponderance of family Libellulidae in both the sites may be due to the fact that it is the largest family of Odonata, tolerant to several anthropogenic impacts and armed with long mid dorsal and lateral spines for avoiding predators. Among the Hemipterans, larger 


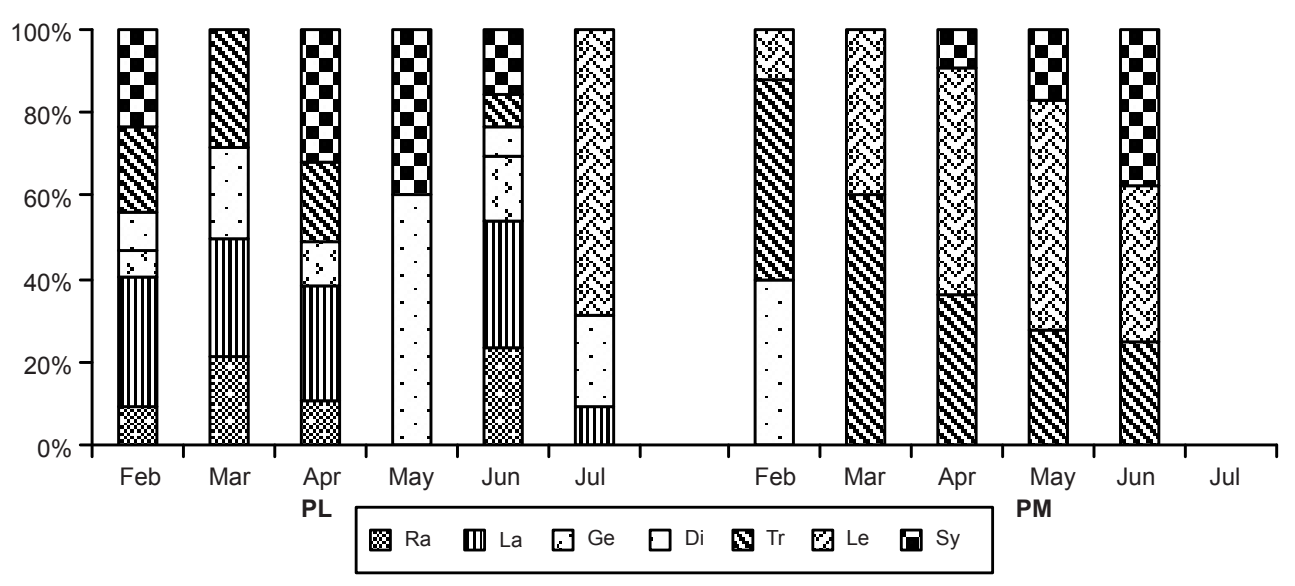

Figure 3. Temporal

fluctuation of percentage relative abundance of different species of insects around Phumdi Live (PL) and Phumdi Mixed (PM) area.

$\mathrm{Ra}$ - Ranatra varipes, La - Laccotrephes ruber, Ge - Gerris sp., Di - Diplonychus rusticus, Tr - Tramea sp., Le - Leucorrhinia sp., Sy - Sympetrum sp.

representation of the family Nepidae in the PL area could be due to the fact that they usually inhabit lentic water where there is plenty of plant material for them to hold as they lie in wait for capturing prey (Usinger 1968; McCafferty 1981). The percentage of relative abundance of different species in the two habitats clearly indicated the preference of Hemipteran insects for PL. Although odonates did not show any differences in the community composition between the two habitats, temporal fluctuations in the percentage of relative abundance of different species were recorded. The absence of Leucorrhinia sp. till the month of June and the sudden recruitment in large number with the highest percentage of relative abundance in the month of July around PL could not be explained. However around PM their continuous increase in percentage relative abundance from February to May, and slight decrease in June indicated their preference for PM (Fig. 3).

The importance of phumdis in maintaining the ecology of the lake has been opined by several workers (Shyamjai 2002; WISA \& LDA 2002). Our study confirmed that the Phumdi Live community of the lake comprising of macrophytes and fresh plants provided better habitat to aquatic insects than that of Phumdi Mixed, which are of value as fish food and in turn fish production. This link between aquatic insects and fish production could perhaps be exploited for better economy of the state.

\section{REFERENCES}

Bath, K.S. \& H. Kaur (1997). Aquatic insects as bioindicators at Harike reservoir in Punjab-India. Indian Journal of

\section{Environmental Science 2: 133-138}

Bal, A. \& R.C. Basu (1994a). Insecta: Hemiptera: Mesovelidae, Hydrometridae, Velidae and Gerridae, pp. 511-534. In: State Fauna Series 3: Fauna of West Bengal, Part 5. Zoological Survey of India, Calcutta.

Bal, A. \& R.C. Basu (1994b). Insecta: Hemiptera: Belostomatidae, Nepidae, Notonectidae and Pleidae, pp. 535-558 pp. In: State fauna series 5: Fauna of West Bengal. Part 5. Zoological Survey of India, Calcutta.

Batzer, D.P., R.B. Rader \& S.A. Wissinger (1999). Invertebrates in Freshwater Wetlands of North America; Ecology and Management. John Wiley and Sons, Inc., New York, 1086pp.

Chilton, E.W. (1990). Macroinvertebrate communities associated with three aquatic macrophytes (Ceratophyllum demersum, Myriophyllum spicatum, and Vallisneria americana) in Lake Onalaska, Wisconsin. Journal of Freshwater Ecology 5: 455-466.

Das, K. \& S. Gupta (2010). Aquatic hemiptera community of agricultural fields and rainpools in Cachar District, Assam, north east India. Assam University Journal of Science \& Technolgy: Biological and Environmental Sciences 5(1): 123-128

Frank, S., S. Goran, K. Judith \& G. Dunja (2005). Behavioural and life history traits in temporary and perennial waters: comparisons among three pairs of sibling dragonfly species. Oikos 108: 609-617.

Hart, D.D. \& V.H. Resh (1980). Movement patterns and foraging ecology of a stream caddisfly larva. Canadian Journal of Zoology 58: 1174-1185

Hazarika, R. \& M.M. Goswami (2010). Aquatic hemiptera of Gauhati University, Guwahati, Assam, India. Journal of Threatened Taxa 2(3): 778-782.

Kaur, H., K.S. Bath, G. Moder \& S.S. Dhillon (2004). Aquatic Invertebrate Diversity of Kanjli Lake, Punjab. Biodiversity and Environment 165-169.

Kight, S.L., J. Sprague, K.C. Kruse \& L. Johnson (1995). Are egg-bearing male water bugs, Belostoma flumineum, impaired swimmers? Journal of Kansas Entomogical Society 68: 468-470. 
Korkeamaki, E. \& J. Suhonen (2002). Distribution and habitat specialization of species affect local extinction in dragonfly odonata populations. Ecography 25: 459- 465.

Kumar, A. (1973a). Descriptions of the last instar larvae of odonata from the Dehra Dun Valley (India), with notes on biology I (Suborder: Zygoptera). Oriental Insects 7 : 23-61.

Kumar, A. (1973b). Descriptions of the last instar larvae of Odonata from the Dehra Dun Valley (India), with notes on biology I I. (Suborder: Anisoptera). Oriental Insects 7: 291-331.

McCafferty, W. (1981). Aquatic Entomology. Boston (MA): Science Books International, Inc., 448pp.

McGavin, G.C. (1993). Bugs of the World. Blandford, London, $193 p p$

Merritt, R.W. \& K.W. Cummins (1996). An introduction to the aquatic insects of North America. Kendall/Hunt Publishing Company, Dubuque Iowa, 862pp.

Muli, J.R., K.M. Mavuti \& Ntiba (2000). Macroinvertebrate fauna of water hyacinth in the Kenyan water of Lake Victoria. International Journal of Ecology and Environmental Science 26 : 281-302.

Parsons, J.K. \& F.A. Malthews (1995). Analysis of the associations between macroinvertebrates and macrophytes in a freshwater pond. North west Science 69: 265-275.

Ramsar Convention Bureau (1997). Ramsar information paper. IUCN The World Conservation Union, Island, Switzerland, 1-14.

Rooke, J.B. (1984). The invertebrate fauna of four macrophytes in a lotic system. Freshwater Biology 14: 507-513.

Rosenberg, D.M. \& V.H. Resh (1993). Freshwater Biomonitoring and Benthic Invertebrates. New York, Chapman and Hall, 448pp.

Salmah, C.R., S.W. Tribuana \& A.A. Hassan (2006). The population of Odonata (dragonflies) in small tropical rivers with reference to asynchronous growth patterns Aquatic Insects 28: 195-209.

Shyamjai, S.S. (2002). Vegetation and phumdi of Keibul Lamjao National Park, pp. 29-36. In: Trishal C.L \& T.H.
Manihar (eds.). Management of Phumdis in Loktak Lake. Proceedings of a workshop held at Imphal, Manipur.

Singh, H.T. (1992). Study of wetland ecosystem of Manipur valley from management perspective of fish, wildlife and environment. Final Report, Department of Science and Technology, Government of India.

Singh, S.R.K. (1999). Project Report of Survey, Documentation and Validation of Infra - Technologies for Fishing Crafts and Gears, Government of India.

Singh, T.S., J.G. Patel, G.S. Rajkumari, N.S. Singh, C.B. Santhosh \& T.H. Manihar (2003). Wetland information systems for conservation and management of Loktak Lake, a project report.

Subramanian, K.A. \& K.G. Sivaramakrishnan (2007). Aquatic Insects for Biomonitoring Freshwater Ecosystems - A Methodology Manual. Asoka Trust for Research in Ecology and Environment (ATREE), Bangalore, India, $31 \mathrm{pp}$

Swanson, G.A., G.L. Krapu \& J.R. Serie (1979). Foods of laying female dabbling ducks on the breeding grounds, pp. 47-57. In: Bookhout, T.A. (ed.). Waterfowl and wetlands - An integrated review, Proceedings of the Symposium, North Central Section of The Wildlife Society.

Usinger, R. (1968). Aquatic insects of California. Los Angelos (CA): University of California Press, 507pp.

Wellborn, G.A.\&J.V. Robinson (1987). Microhabitat selection as an antipredator strategy in the aquatic insect Pachydiplax longipennis Burmeister (Odonata: Libellulidae). Oecologia 71: 185-189.

Westfall, M.J. Jr. \& K.J. Tennessen (1996). Odonata, pp. 164-211. In: Merrit, R.W. \& K.W. Cummins (eds). An Introduction to the Aquatic Insects of North America- $3^{\text {rd }}$ Edition. Kendell/Hunt Publishing Company. Dubuque, Iowa.

WISA \& LDA (2002). Management of Phumdis in Loktak Lake, pp. 9-23. In: Trisal, C.L \& T.H. Manihar (eds.). Proceedings of a Workshop held at Imphal, Manipur.

ZSI (2004). State Fauna Series 10: Fauna of Manipur, (Part-2) Insects. Zoological Survey of India, Kolkata, 625pp. 